\title{
Die aard van wet in die Pentateug: 'n Krities-kanoniese perspektief met Nuwe-Testamentiese implikasie
}

\author{
De Koning, Jacobus de Wit \\ Noordwes-Universiteit \\ jdwkoning@gmail.com
}

\begin{abstract}
The nature of law in the Pentateuch: A critical-canonical perspective with New Testament implication

In this study, the question is asked whether the nature of law in the Pentateuch corresponds with the view of the nature of the law as expressed by the Westminster Confession of Faith. The article also explores whether Calvin's view of the law, as sometimes emerged in his discussion of the guideline for the Christian's life of gratitude, may not be more in line with it, especially when he sees Christ and the law as interchangeable when it comes to a guideline for Christian life. In the search for an answer to this question, the article looks at researchers' critical investigation into the authority that legal material in the Pentateuch actually had in the practice of Israel and Judah, in conjunction with a canonical investigation into the nature of the legal material in the Pentateuch. After indication of an implication of this findings for the New Testament Christian, the article comes to the conclusion that Calvin was indeed at times closer to the nature of law in the Pentateuch than the Westminster Confession of Faith.
\end{abstract}

Key words

Westminster Confession of Faith; Calvin; law; Pentateuch covenant; Torah; Jesus the Torah

\section{Inleiding}

Hesselink (1997:83) het oortuigend aangedui dat daar vir Calvyn geen teenstrydigheid is nie om soms na die wet en ander tye na Christus te verwys as die norm of reël vir die Christelike lewe; of anders gestel: as die uitdrukking van God se wil. Tog is dit uiters betekenisvol dat wanneer 
Calvyn die Christelike lewe bespreek, hy eerder na Christus as na die wet verwys. Christus is die model en beeld waarna God ons wil verander. Hy stel dit kragtig: "En om ons nog beter tot besinning te bring, toon die Skrif ons dat God die Vader, soos Hy ons in sy Gesalfde met Hom versoen het, so in Hom vir ons 'n beeld afgestempel het, en Hy wil hê dat ons daaraan gelykvormig moet word" (Calvyn 1984: Inst. 3.6.3).

Wanneer daar na die Westminster Confession gekyk word, is daar aanduidings van 'n klemverskuiwing. Die Sabbatgebod kan as lakmoes gebruik word. Volgens die Westminster Confession, het God,

... in his Word, by a positive, moral, and perpetual commandment binding all men, in all ages, ...particularly appointed one day in seven for a Sabbath to be kept holy unto him ...the first day of the week, which, in Scripture is called the Lord's Day, and is to be continued to the end of the world, as the Christian Sabbath ...(par. 21.7).

Indien bogenoemde belydenisskrif se hantering van die Sabbat as lakmoestoets gebruik word vir die wyse waarop hulle die funksionering van die sedewet in die Christen se lewe sien, kry'n mens dus baie sterk die indruk dat die model en beeld, waarna ons moet beweeg, nie Christus is nie, maar die "law, as a covenant of works" (par. 19:1) wat reeds in Adam se hart geskryf is en steeds "...the perfect rule of righteousness after the Fall" (par. 19:2), is.

Paragraaf 19:5 van die Westminster Confession skep die indruk dat Christus ons juis help om hierdie maatstaf te bereik:

The moral law does forever bind all, as well justified persons as others, to the obedience thereof; and that, not only in regard of the matter contained in it, but also in respect of the authority of God the Creator, who gave it. Neither does Christ, in the Gospel, in any way dissolve, but much strengthens this obligation.

Die vraag op die tafel is dit: Watter siening van die wetlike materiaal in die Ou Testament as riglyn vir die Christen se lewe, laat reg geskied aan die aard van die wetsmateriaal in die Ou Testament?

Anders gestel: Is die hantering van die wetlike materiaal as "binding all men in all ages" en die siening dat Christus ons verplig om die morele wet 
te hou, in lyn met die aard van daardie materiaal in die Ou Testament self? Is hierdie materiaal in die praktyk van die $\mathrm{Ou}$ Testament op so 'n wyse hanteer? Kan daar gesê word Christus "strengthens this obligation"? Of is Calvyn se siening meer in lyn met die aard van die Ou-Testamentiese wetsmateriaal as hy die wet van Moses en Christus as uitruilbaar gebruik wanneer dit gaan oor die riglyn vir die Christelike lewe?

Om hierdie vraag te beantwoord gaan daar eerstens gekyk word na betekenisvolle $\mathrm{Ou}$ Testamentiese navorsing in die laaste dekades wat gepoog het om vas te stel of daar 'n ooreenkoms is tussen werklike wetgewing in Israel en Judea en die wetgewing wat gevind word in die Pentateug.

\section{Die kritiese vraag na die gesag van wetlike materiaal in die Pentateug in die praktyk van Israel en Juda}

In die beantwoording van die vraag of daar 'n ooreenkoms is tussen werklike wetgewing in Israel en Juda en die wetgewing wat in die Pentateug gevind word kan daar in die eerste instansie 'n tradisionele siening onderskei word wat steeds deur geleerdes soos Fisbane (1985:95), Patrick (1985:198) en Watts (1999:136-137) onderskryf word. Hiervolgens was die wetlike materiaal van die Pentateug 'n samehangende wetsisteem wat as die gesagvolle wet in antieke Israel en Juda gefigureer het.

'n Hele aantal geleerdes sien nie die verskillende wetlike versamelings in die Pentateug as 'n samehangende wetsisteem nie. Veel eerder is hierdie 'kodes' by tye in kompetisie met mekaar, tot so 'n mate dat gedeeltes van een kode selfs kan verskil van 'n ander of kan poog om ander gedeeltes van dieselfde kode te hersien. So was daar baie debat rondom die Verbondskode en die Deuteronomistiese kode (Wells 2008:227). Laasgenoemde sou 'n poging wees om die wette in eersgenoemde te transformeer. Die mate van hierdie transformasie is egter ' $n$ punt van dispuut. Van belang in hierdie

1 Wells (2009:2842) maak die volgende belangrike opmerking wat betref die term "kode": The term "code" is really a misnomer, since neither these codes nor the ones in the Bible fit the definition of a modern law code. First, all are far from comprehensive in scope and omit a number of expected topics. Second, their content sounds much more like case law than legislation. Most of the provisions in the codes present possible cases usually beginning with "if" - and then give a ruling for that case. Third, scholarship on the codes is now generally agreed that the purpose of these written collections was not to establish law in their respective societies. 
verband is Eckard Otto se bydrae. Volgens hom het die Pentateug wette hulle oorsprong te danke aan priesterlike skole eerder as aan wetgewende aktiwiteit per se. Hy argumenteer dat Judaïese priesters, veral die wat verantwoordelik was vir Deuteronomistiese wet, hierdie materiaal egter bymekaar gebring, verander en daarby gevoeg het om sodoende bindende wet te skep wat goddelike goedkeuring gehad het en belangrike sosiale, politieke en wetlike aspekte van die Judese gemeenskap hervorm het. Hy argumenteer dan ook dat die Deuteronomistiese kode 'n poging was om die manier waarop die wette van die Verbondskode gebruik is, te verander deur hierdie wette te herinterpreteer in die lig van die Deuteronomiese agenda van kultiese sentralisering (Otto 1996:112-122).

Wells (2008:227) wys daarop dat iemand soos Bernard M Levinson egter aandui dat daar nie net sprake is van 'n herinterpretasie nie, maar 'n totale hersiening van godsdiens, wet en sosiale strukture deur hierdie skrywers van die Deuteronomistiese kode.

Daar moet genoem word van die denkskool wat van mening is dat die wetskodes in die Pentateug bloot akademiese werke is soos ook in die res van die antieke Ou Nabye Ooste gevind. Dit is dus bloot van teoretiese belang met geen pratiese wetlike funksie in die samelewing nie (Bottéro 1992:156-184; Fried 2001:72-84).

Meer oortuigend is die geleerdes wat aandui dat hierdie wette wel gebruik is in die samelewing maar nie as preskriptiewe wet gefunksioneer het nie, maar eerder as deskriptiewe wet (Westbrook 1989:201-222). Hand aan hand hiermee gaan die siening dat hierdie kodes gefunksioneer het in morele berading en eerder 'n wysheids- as 'n wetlike gerigtheid gehad het (Westbrook 1989:204).

Wells (2008:232-243) kom na 'n indringende ondersoek na die verskille en ooreenkomste van die wetskodes in die Pentateug met die wette van Hammurabi ${ }^{2}$ tot die konklusie dat die siening dat die wetlike materiaal in die Pentateug bloot teoreties en van akademiese belang was nie water hou nie. Sy persoonlike siening is dat die siening van die kodes as deskriptief

2 Die rede waarom hierdie wetskodes gebruik kan word, is natuurlik daarin geleë dat daar wel (anders as in die geval van die Bybelse materiaal) geskrifte beskikbaar is wat gebruik kan word om aan te dui of hierdie wette wel werklik in die praktyk gefunksioneer het al dan nie. 
van aard die bevredigendste antwoord vir die meeste van die materiaal in die Pentateug gee, alhoewel daar gevalle is (bv die voorsienings wat die gesentraliseerde aanbidding bevorder en wat die mag van die koning reguleer) waar'n kombinasie van die tradisionele siening en die van iemand soos Otto wel geldig kon wees.

Die skrywer van hierdie artikel vind die meeste aanklank by die onlangse werk van Krause (2015:8) wat argumenteer dat ons in die wetlike materiaal van die Pentateug te make het met idealistiese deskriptiewe wet in die sin dat dit die wetgewer beskryf asook ideale verbond getrouheid. Hand aan hand hiermee gaan natuurlik konsekwente interpersoonlike verhoudinge tussen lede van die verbond en uiteindelik "judicial wisdom” wat deur 'n rigter, koning of magistraat opgesoek kon word om regverdige uitspraak te gee. Iemand soos Milgrom ${ }^{3}$ (2004:30) se siening van die rol van die rituele in Levitikus wanneer hy opmerk; "biblical rituals are symbolic acts that, in the main, contain within them ethical values", is ook van uiterse belang want dit onderstreep weereens dat ook die rituele nie net as onveranderlike instellings of wette gegeld het nie maar wel etiese waarde gehad het binne die geheel waarin dit gefunksioneer het.

Dit is nou belangrik om uit 'n Kanoniese oogpunt te gaan kyk na die aard van die materiaal wat ons in die Pentateug vind om te sien of dit in ooreenstemming of in stryd is met voorafgaande insigte alvorens daar beweeg word na die Nuwe Testamentiese implikasie hiervan.

\section{Die kanoniese antwoord op die aard van die wetlike materiaal in die Pentateug}

\subsection{Leksikaal: Die betekenis van wet as Tora}

Daar moet met Dumbrell saamgestem word dat die woord Tora veel meer as blote 'wet' is (Dumbrell 1984:91). Hierdie siening word bevestig wanneer daar na die woord self gekyk word. Dit dui hoegenaamd nie op statiese verwagtings wat die geheel van menslike ervaring beheer nie. Die woord Tora kom van die Hebreeuse werkwoord بִרָָ wat die betekenis het

3 Milgrom onderskryf'n voorballingskapdatum vir die Heiligheidskode (H), en assosieer dit sodoende met die hervormings van Hiskia. 
van 'om te gooi' of 'om te skiet'. In die Hiphil-stamformasie neem dit die betekenis aan van 'om te onderrig, om die rigting aan te dui uit' soos in Eksodus 35:34 en Levitikus 10:11 (vgl Koehler \& Baumgarten 1958:1023; Brown, Driver \& Briggs 1966:435-436; Kaiser 1996:192).

Die feit dat die Tora meer as blote wet is, is duidelik uit die gebruik van die selfstandige naamwoordsvorm van die werkwoord ירָָ in Eksodus 24:12 in verband met Tora:

"Toe sê die HERE vir Moses: Klim op die berg na My toe en vertoef daar, dat Ek jou die kliptafels kan gee en die wet וְרוֹ en en gebooie

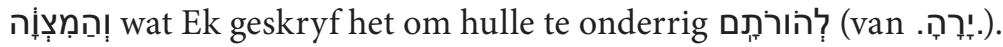

Ander gedeeltes wat duidelik daarop dui dat Tora nie bloot vir wetlike doeleindes gebruik word nie, sluit die volgende in:

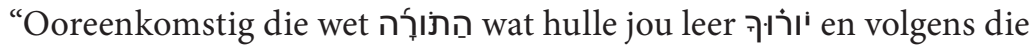
regspraak wat hulle jou sê, moet jy handel; jy mag nie regs of links afwyk van die uitspraak wat hulle jou te kenne gee nie" (Deut 17:11). "Neem jou in ag by die plaag van melaatsheid om baie noukeurig te handel volgens alles wat die Levitiese priesters julle sal leer iاרו" (Deut 24:8).

En baie interessant vind ons in Jesaja 2:2-3:

En aan die einde van die dae ... baie volke sal heengaan en sê: Kom laat ons optrek na die berg van die HERE, na die huis van die God van Jakob, dat Hy ons sy weë kan leer ì en ons in sy paaie kan wandel. Want uit Sion sal die wet תוֹ תוֹ uitgaan en die woord van die HERE uit Jerusalem."

Hierdie laaste gedeelte wat ook die Tora met lering en instruksie verbind, is insiggewend aangesien hier 'n heenwys is na die Messiaanse era. Die Tora sal in hierdie tyd nie die funksie van blote wetlike verpligtinge hê wat nagekom moet word nie, maar dit sal dien as middel tot rigtinggewing en leiding sodat die volk volgens die wil van die Here kan leef.

\subsection{Tora en verbondsverhaal}

Wanneer daar gedink word oor die aard en funksie van die Tora binne die kanon, is dit van kardinale belang om te verstaan dat die wetlike materiaal van die Ou Testament nooit in isolasie voorkom nie. Trouens, die Tora is 
ingebed in Israel se teologiese geskiedenis. Dit is 'n integrale deel van die storie wat vanaf Genesis 12 tot en met 2 Konings 25 loop. Die Tora word nooit op sigself as 'n losstaande, tydlose universele kode voorgehou wat vir gedrag voorgeskryf word nie. Veel meer word dit voorgehou as deel van die teologiese verhaal wat beskryf hoe God Israel uit Egipte verlos en dan in die beloofde land as sy Volk vestig (Hays 2001:25).

Die sleutel tot die kombinasie van Tora en narratief lê in Deuteronomium 1:1 tot 4:43. Die redakteur maak dit duidelik dat Moses onderneem om die Tora te verklaar; met ander woorde, Moses gaan nou sê wat Tora is (1:5). Maar dan vind ons dat hy'n gedeelte van die voorafgaande Pentateug narratief verduidelik, onder andere die rebellie by Kades-Barnea (Numeri 13-14). Moses se toespraak bestaan uit interpretasie en kommentaar op die verhaal se betekenis vir sy teenwoordige gehoor. Hy vertel nie net die Tora oor nie, maar verduidelik dit ook. Moses is as't ware verteller sowel as prediker. Die resultaat hiervan is dat die narratief self 'n vorm van instruksie is. Meer as dit; dit is betekenisvol dat die redakteur die woord Tora gebruik en nie 'n ander woord vir lering, soos byvoorbeeld לִַמָ in 4 vers 1 en 5 nie. In die konteks van dit wat ontvou in Deuteronomium, vorm die verhaal as instruksie 'n bevel aan Moses se luisteraars, aangesien narratief as Tora nie verstaan kan word los van die verbondskonteks van Moses se testament nie. Uiteindelik, na die aanhoor van die verhaal, kan daar net op twee maniere gereageer word: "As gevolg van hierdie verhaal, aanvaar ek die verbond", of, "Ten spyte van hierdie verhaal, verwerp ek die verbond." Aanvaarding of verwerping sal uiteindelik bepaal of die seën of vloek ontvang word. Die gewigtigheid van die bevel is dus baie duidelik (Mann 1988:146-147).

Daar is nou aangedui dat die wet (Tora) deel uitmaak van die Pentateug narratief en ingebed is in Israel se eksodus, omswerwinge en oorwinnings. Die implikasie hiervan is duidelik:

Die wetsgedeeltes in die Pentateug dieselfde geldigheid en toepaslikheid as die verhalende gedeeltes het, en anders om. ${ }^{4}$ Dit vorm 'n onlosmaaklike eenheid.

4 Dit is interessant om daarop te let dat wanneer die dissipels graan op 'n Sabbat pluk en die Fariseërs hulle aankla dat hulle die Sabbatswet verbreek soos in Eksodus 34:21 
Voortvloeiend hieruit bevestig dit die absolute eenheid tussen die sogenaamde morele, burgerlike en seremoniele wette wat oortuigend deur verskeie teoloë deur die jare uitgewys is (Wenham 2003:73; Poythress 1991:99-101, Hays 2001:24).

Dit het nou reeds deurgeskemer dat die Tora as 'n eenheid in 'n verbondskonteks gegee word. Let op Eksodus 19:5: "As julle dan nou terdeë na my stem luister en my verbond hou, sal julle my eiendom uit al die volke wees, want die hele aarde is myne." Die volk stem in om die voorwaardes van die verbond na te kom en antwoord: "Al die woorde wat die HERE gespreek het, sal ons doen." Hierdie ooreenkoms word deur Moses met bloed beseël: "Toe neem Moses die bloed en gooi dit uit op die volk en sê: Dit is die bloed van die verbond wat die HERE met julle gesluit het op grond van al hierdie woorde."

'n Uiters belangrike deel van hierdie verbond God se belofte om in Israel se midde te woon. Dit word verskeie kere in die latere gedeeltes van die boek Eksodus beklemtoon $(25: 8 ; 29: 45 ; 33: 14-17 ; 40: 34-38)$. Hand aan hand met God se teenwoordigheid gaan die instruksies vir die ark en die tabernakel wat die plek is waar God sou woon (Eksodus 25-31, 35-40).

Levitikus is daarom die natuurlike vervolg van die tweede gedeelte van Eksodus, aangesien dit die vraag aanspreek van hoe Israel behoort te lewe wanneer God in hulle midde is. Levitikus gee die antwoord op hierdie vraag met praktiese riglyne vir die lewe saam met God onder die terme van die Mosaïese verbond. Na Israel se weiering om die beloofde land in te gaan (Num 13-14), laat God toe dat die ongehoorsame generasie sterf. Hy lei die volk dan terug na Kanaän toe. Alvorens hulle ingaan, roep Hy hulle egter op tot verbondsvernuwing. Deuteronomium beskryf hierdie verbondsvernuwing. ${ }^{5}$ Ons vind in fyn besonderhede die terme waaronder Israel in die beloofde land suksesvol sou lewe en deur God geseën sou word.

gestel, Jesus die oënskynlike verbreking van die Sabbatswet regverdig deur uit 'n narratiewe gedeelte in 1 Samuel 21:1-9 aan te haal (Markus 2:23-28).

5 Die studie van antieke susereine verdrae (dit wil sê verdrae wat afgedruk is deur 'n veroweraar - die suserein of opperleenheer - op 'n verowerde nasie oftewel die vasal, wat dan verplig was tot 'n verbondsverhouding), openbaar, wat gesien is as belangrike parallelle met die Bybelse wetskode. Hierdie siening is met ywer deur Merdith Kline toegepas op die boek Deuteronomium en ook die Dekaloog (Kline 1963). 
Dat die Tora onlosmaaklik verweef is met die verbond, is onbetwisbaar. ${ }^{6}$ Anders gestel: die Tora in sy geheel is die verbondsdokument van die ou verbond. Dit impliseer dat die Tora staan en val as 'n enkel entiteit.

\subsection{Tora, hart en geloof}

Die Tora het ten doel om God se mense innerlik te verander om gelykvormig aan Hom te wees (Krause 2015:5). Die hartsverandering (of tekort aan hartsverandering) kom op baie plekke in die Bybelse teks na vore. Levitikus 19:17 maak dit byvoorbeeld duidelik dat geen Israeliet sy broeder in sy hart moes haat nie. Voorts praat Levitikus 26:41 oor die "onbesnede hart" wat moet nederig word en Deuteronomium 4:29 roep die Israeliete op om die Here te soek met hulle hele hart en siel. Krause (2015:5) wys daarop dat die hele saak van die hart sekerlik die duidelikste na vore kom in die Shema van Deuteronomium 6:4. In die onmiddellike konteks identifiseer Moses die verbondsgod wat hulle uit slawerny bevry het (vers 4). Hy is JAHWE en Sy identifikasie stem ooreen met die proloog van die Dekaloog in Eksodus 20:2 waar JAHWE Homself bekendmaak voor Hy die gebooie gee. Net hierna word daar in Deuteronomium 6:5 duidelike aanduidings gevind dat ons nie te doen het met blote preskriptiewe wet nie aangesien hulle gehoorsaamheid nie bloot ekstern mag wees nie. Moses se verwysing na "hart", "siel" en "krag" maak dit duidelik. Die hart word weer beklemtoon in vers 7 en funksioneer as 'n soort parallelisme weens sy herhaling. Uiteindelik beskryf Deuteronomium 6:8-9 die ooreenstemmende optrede van 'n werklik veranderde hart. Elkeen van die frases wys op die uitwerking van die innerlike verandering

Waar dit oor die hart gaan kom geloof ter sprake. Reeds in die tagtigerjare dui Schmitt (1982:170-189) aan dat die mees kenmerkende verskynsel in die redaksionele "nate" van die Pentateug juis die konsekwente gebruik van

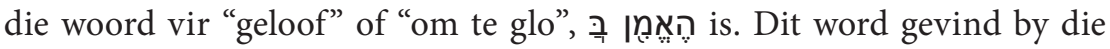
kritieke oorgangspunte tussen gedeeltes binne die hele korpus. Hy wys die

6 Geleerdes sien wel nie meer A. Alt se teorie van apodiktiese wet as 'n bewys van die verband tussen wet en verbond nie, aangesien dit eie is aan Israel. Navorsing wys uit dat antieke Ou Nabye Oosterse parallelle tot hierdie tipe wet bestaan. Iemand soos W. Zimmerli het egter weer die verband tussen wet en verbond op die voorgrond geplaas deur te wys op die feit dat Israel se wet altyd verband hou met $v$ loek; vloek wat veroorsaak dat die verbond in gevaar kom, ja selfs vernietig kan word (Preuss 1995:88,90 e.v.). 
volgende sleuteltekse uit: Gen 15:6, Eks 4:5, Eks 14:31; Num 14:11, Num 20:12. Kaiser (1996:194) meen Genesis 45:26 en Deuteronomium 1:32 en 9:23 kan ook bygevoeg word.

Die implikasie hiervan, soos Kaiser (1996:194) tereg aandui, is dat geloof aan die hart van die Tora lê. Dit is opvallend dat in elkeen van hierdie tekste, geloof verbind is met die konsep van die "hou van God se Tora." Die teenoorgestelde is natuurlik dan ook waar: waar geloof afwesig is, lei dit tot rebellie teen God se wet. Die teologie van vertroue en geloof is dus bedoel om die teologie van bevele en bepalinge te beheer.

Sailhamer (1991:254) maak in hierdie verband 'n belangrike opmerking:

It is as if the author of the Pentateuch has seized on the Abrahamic narratives as a way to explain the concept of "keeping" the law. The author uses the life of Abraham, not Moses, to illustrate that one can fulfill the righteous requirements of the law. In choosing Abraham and not Moses, the author shows that "keeping the law" means "believing in God," just as Abraham believed God and was counted righteous (Gen 15:6). In effect the author of the Pentateuch says, 'Be like Abraham. Live a life of faith and it can be said that you are keeping the law.

In 'n uiters sinvolle en weldeurdagte bydrae oor die Pentateug wys Loader (Loader 2001:70-85) daarop, dat in die lig van die buigbaarheid van die term "tema", die tema van die Pentateug uitgedruk kan word in die term Tora. Maar wát Tora is, word volgens Loader duidelik in die interverhouding tussen die motiewe van Goddelike voorsiening, of "evangelie", en gehoorsaamheid wat verwag word van mense: "wet." Hierdie tema word volgens hom dwarsdeur die Pentateug gevind. Anders gestel, die wetlike "blokke" in die Pentateug is, soos daar nou reeds aanggedui is, geïnkorporeer in die narratiewe materiaal. Soos hy dit stel: "a lawincorporating gospel is Torah” (Loader 2001: 75 vgl ook Ryken 2003:27).

\section{Jesus die Tora}

Krause (2015:10-12) plaas die Persiese era sowel as die Hellenistiese era onder die loep en dui aan dat die omkeer van deskriptiewe wet na preskriptiewe wet onder die Joodse volk in hierdie tyd plaasgevind het. 
Jesus bring juis in Sy bediening 'n korreksie aan op hierdie preskriptiewe benadering as $\mathrm{Hy}$ die hart en geloof weer in die sentrum plaas van dit wat God behaag (vgl. bv. Matt 23:23-24 en Matteus 5-7). Jesus was daarom ten diepste volgens Krause (2015:13) 'n hervormer.

Maar Jesus was meer as dit. Allison (1993:187) toon aan dat die Hebreeuse ekwivalent van Galasiërs 6:3 se 'wet van Christus', naamlik die woorde, 'Tora van die Messias', in Mid Qoh. 11:8 voorkom. Hieruit blyk dit dat 'n groepering binne pre-Christen Judaïsme reeds van 'n Messiaanse Tora gepraat het.

'n Deeglike studie van Matteus 1 tot 5 en spesifiek Matteus 5:17-21 (Dumbrell 1981:10; Holwerda 1995:119; Carson 1984:145; France 1985:115 en Van Bruggen 1999:92) bring 'n mens so ver om op spoor van Allison (1993:187) te sê dat Matteus Jesus as die nuwe wetgewer, die eskatologiese interpreteerder van die Tora, voorhou. Dit is hierdie Tora wat Jesus inderdaad kom instel het, wat Hyself in werklikheid beliggaam. Dit is ook hierdie Tora, dus Jesus self, wat die vervulde Tora van Matteus 5-17 is. Hierdie Tora is nie 'n vernietiging van die ou Tora nie, maar die vervulling daarvan tot'n ongekende volheid.

NT Wright sluit hierby aan as hy die stelling maak:

...Torah was at one and the same time the charter of the people of God and the full and final revelation of God himself. If then Jesus has taken on this double role, it is no surprise to find him taking on precisely the role of Torah in Paul's understanding of the plan of the one God (Wright 2004:266).

In sy boek, The climax of the covenant, wat in 2004 verskyn, wys hy daarop dat Israel die posisie van Adam oorneem en dat die Jode bewus was dat hulle, as die nageslag van Abraham, op die een of ander wyse die herstel van die wêreld gaan bewerk in die lig van Genesis 12:1-3. Hulle was egter vas oortuig dat jy deel het aan hierdie Israel, deur wie God die herstel gaan bring as jy die "die werke van die wet" gaan onderhou. Dit beteken deur die besit van die Tora met alles wat dit behels en deur al die voorskrifte en taboes en feeste te onderhou, is en word jy deel van Abraham se nageslag, die mense wat die wêreld se herstel op een of ander wyse sal bewerk. Hulle het hulleself egter gesien as tans in ballingskap en verwag dat God 'n finale bevryding gaan bring waarin hulle die rol gaan speel as herstellers van 
wêreld. En nou baie belangrik: God se getrouheid aan Sy verbond was op die spel. God kan nie Sy verbond, Sy beloftes aan Abraham en Israel verbreek nie. En natuurlik is Israel se God ook die Skepper van die wêreld! (Wright 1996:23 e.v.)

Wat Paulus volgens Wright in die Romeine brief doen, is om te wys dat God getrou is aan Sy verbond. God handhaaf Sy geregtigheid. Maar Paulus wys dat God nie meer fisiese Israel gebruik om die wêreld te herstel en die verbond te bevestig nie, maar Jesus as die verteenwoordiger van Israel. In een van sy nuutste werke, The Day the Revolution Began: Reconsidering the Meaning of Jesus's Crucifixion, wat in 2016 verskyn wys Wright daarop dat God in Sy verbondsgetrouheid sy volk straf het en juis as gevolg daarvan vind die Ballingskap plaas (Wright 2016:304 vgl ook Wright 2004:140).

In Romeine 3:21, beteken die dikaiosynē theou dan ook volgens hom "God's covenant justice/faithfulness," en sondaars word vrylik verklaar as in die reg, dikaioumenoi, met Hom en dus as lede van die verbond ${ }^{7}$ deur die verlossing wat bewerk is deur Jesus die plaasvervangende verteenwoordiger van Israel. Alhoewel hierdie lees van dikaiosyne theou nie deur alle kenners van Romeine aanvaar word nie (Moo 2000:124-127), is dit moeilik om met geleerdes soos Dunn (1988: 40-48, 97) en Hayes (1993: 34-53) wat hierdie interpretasie $^{8}$ onderskryf te verskil.

Die skokkende vir die Jode moes volgens Wright geleë wees in die feit dat jy deel het aan hierdie "Israel" (Jesus) nie deur die "werke van die wet (Tora)" nie, maar deur die geloof in Hom wat gedoen het wat Israel nie kon doen nie, deur Sy dood en opstanding. In en deur Jesus het die finale uittog of verlossing uit ballingskap aangebreek en kan die land (nuwe aarde, wêreld) verkry word. En deur hierdie werk van Jesus word die Gees gegee in die plek van die Tora om die lewe te leef wat God behaag (Wright 2016:305; Wright 2004:146 e.v.).

7 Wanneer hierdie uitleg aanvaar word maak Romeine 4 natuurlik ook heeltemal sin. Paulus moet nou wys wie is die verbondsfamilie waarvan jy deel word deur die geloof.

8 Daar moet nie afgelei word dat hierdie siening net deur sogenaamde New Perspective voorstanders onderskryf word nie. Geleerdes soos Adolf Schlatter, Walther Eichrodt, Gerhard von Rad, Ernst Käsemann, Peter Stuhlmacher, Karl Kertelge, Ulrich Wilckens, Elizabeth Achtemeier, Michael Bird, nsomeer onderskryf ook hierdie interpretasie. 
Anders gestel, die "verbondslewe" wat die Tora belowe het, maar nie kon gee nie (Rom 8:3), kon nou waarlik kom (Rom 8:4)9 - die "lewe" wat verloor is by die skepping en nou finaal as "ewige lewe" of opstandingslewe van die nuwe era geopenbaar word. Dat dít die gedagte by Paulus is, word nie net duidelik deur sy hele gedagtelyn in Romeine 8 nie, maar ook uit die aanduidings daarvan in Romeine 7:10 (die gebod wat die lewe moes gee) en Galasiërs 3:21 (as daar'n wet gegee was wat die krag het om lewend te maak). Die Tora bring dus uiteindelik hierdie lewe, maar juis deurdat dit sonde op 'n hoop stapel op Israel, in Israel se verteenwoordiger: die Messias (Jesus); sodat God dit daar kan straf en juis deurdat die Tora só eintlik self verdoem word, kan lewe kom. Die Tora bereik dus die doel waarvoor dit gegee is, op paradoksale wyse, in die geskiedenis.

In kort, gelowiges in die Nuwe Testament leef onder Jesus die Tora. ${ }^{10}$ Jesus in wie Wet en Evangelie in volmaakte harmonie verkeer. Wanneer daar in gedagte gehou word wat die aard van die Tora is, kan daar afgelei word dat 'wet' onder Jesus die Tora ook onderhou word deur geloof vanuit die hart en in lyn met die deskriptiewe aard van die Tora is daar vryheid onder Jesus die Tora. Dit bring ons by 'n implikasie van hierdie studie vir Nuwe Testamentiese gelowiges.

\section{Nuwe-Testamentiese implikasie}

\subsection{Vryheid en liefde}

Die kritiese sowel as die kanoniese ondersoek in hierdie studie het aangedui dat die Tora, of 'n gedeelte van die Tora nooit op sigself as 'n losstaande, tydlose universele kode vir gedrag voorgeskryf word of kan word nie.

God wou gehad het dat Israel oorvloedig en vrygewig moes wees in dit wat God aan hulle gegee het, en Hom sou erken as die Gewer en Besitter van

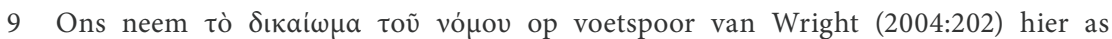
verwysende na die "lewe" op grond van die algemene gedagtegang in Romeine 8 sowel as die verwysings in Romeine 7 en Galasiërs 3.

10 Verskeie teoloë deur die jare sien Jesus self as die Tora: So byvoorbeeld skryf Moltmann (1967:193)."The central place of the Torah in late Jewish apocalyptic is...taken by the person and the cross of Christ" Gese (1981:89) kan na aanleiding van Bybels teologiese eksegese oor Jesus se verheerliking op die berg die volgende opmerking maak: "The gospel writers could not present it more powerfully: Jesus himself is the Torah.” 
alles. Om hulle hierin te help, het Hy hulle kinderlike opvoedingsregulasies gegee soos tiendes, eerste vrugte offers, dankoffers, en so meer. Hierdie regulasies was nie permanent nie.

Dit was tydelike regulasies, totdat Christus, die een wat die Tora en sy aard kom vervul, sou kom.

Die Nuwe Testament wil nog meer hê dat God se mense vrygewig moet wees met sy gawes en dat hulle sy aanspraak op alles wat hulle is en het, sal raaksien. Maar die Nuwe Testament gee nie regulasies oor byvoorbeeld tiendes en offerandes nie. In sy brief aan die gemeentes roep Paulus die mense op tot vrygewige bydraes en verantwoordelike rentmeesterskap.

Indien Paulus byvoorbeeld Ou Testamentiese regulasies in verband met tiendes sou wou gee, het hy 'n gulde geleentheid hiertoe gehad. Hy reken die gemeente egter as 'n gemeenskap wat volwasse geword het onder die evangelie. Terwyl hy by hulle aandring om die "geregtigheid van die wet" te praktiseer, druk hy nie die regulasies van die wet op hulle af nie.

Die wet van Moses bevat wel regulasies in verband met tye en plekke van aanbidding, maar die Nuwe Testament het geen begeerte om sulke wette neer te lê nie. Dit is duidelik dat Paulus nie wil toelaat dat regulasies in verband met heilige dae en Sabbatte afgedruk word op die gewetens van die gemeente nie (Rom 14:5; Gal 4:10; Kol 2:16).

Natuurlik het die kerk steeds tye en plekke van aanbidding nodig. Gees het steeds vorm nodig - dit wil sê: waar daar geloof is, sal daar goeie werke wees; waar daar 'n gemeente is, sal daar regering en orde wees; waar daar evangelie is, sal daar sakramente wees.

Waar die wet van Moses egter spesifieke voorskrifte in verband met die vorme gee, het die Nuwe Testamentiese gemeenskap baie meer vryheid. Aangaande die Nagmaal sê Jesus: "doen dit tot my gedagtenis" (1 Kor. 11:24). Hy spesifiseer egter nie dat dit byvoorbeeld in die aand gedoen moet word nie (soos die Pasga) of op 'n sekere dag (soos die Sabbat) nie.

Dit is natuurlik nie vreemd dat die kerk dikwels beïnvloed is deur sy Joodse wortels nie. Soos die dienste van die Joodse sinagoge, bestaan die kerk se liturgie uit Skrifvoorlesing, gebede en psalms en gesange. Die regering van plaaslike ouderlinge lyk soos die regering van plaaslike sinagoges. Net soos Judaïsme 'n heilige jaar het (Paasfees, Pinkster, Dag van Versoening, 
Loofhuttefees, ens.), so was die kerk geneig om 'n liturgiese jaar te ontwikkel wat die groot momente van die Christelike gebeure vier. Soos die sinagoge elke week vergader, so kom die Christelike gemeente elke week bymekaar. In al hierdie sake is daar egter 'n groot verskil tussen Judaïsme en Christendom: Die Christelike kerke het groot vryheid om hulle vorme aan te pas by die kultuur waarin hulle hul bevind.

Hierdie vryheid wat bestaan in die tydperk van Christus die Tora, moet egter altyd in die lig van liefde verstaan word. Weer en weer sien ons in die Nuwe Testament dat liefde die kern van die nuwe "wet", oftewel Christus die Tora, is. Hyself is immers liefde as die Een wat God is. Etiese prediking wat die vryheid beklemtoon onder Christus die Tora, moet daarom terselfdertyd klem lê op liefde. Sonder hierdie klem sal die gemeente nie 'n voorstelling van Jesus self aan die wêreld wees nie.

In sy uitstekende werk, Resurrection and Moral Order, waar hy'n raamwerk vir evangeliese etiek deurgee, maak Oliver O'Donovan waardevolle opmerkings wat betref die Gees, vryheid en liefde (O'Donovan, 1994:101 e.v.). Hy wys daarop dat die pinkstergawe beteken dat die vernuwing van die heelal my raak op die punt waar ek 'n morele agent is; waar ek handel en kies en myself as "ek" ervaar. Dit beteken dat, in die verlossing van die wêreld, ek as gelowige myself oorgee aan God se orde en vryelik my plek daarin inneem.

O’Donovan (1994:31 e.v.) wys dat in Jesus se opstanding, hierdie morele orde publiek en kosmies in die gelyk gestel is deur God. Jesus is nie net getuie tot die herstelde morele orde nie, maar Hy is die een in wie die orde gekom het; God het gewil dat die herstelde skepping vorm sou aanneem in, en in verhouding tot een Man. Hy bestaan nie net as voorbeeld en prototipe nie, maar as die Een in wie dit opgesom is. Om deel te hê aan die nuwe skepping is om deel te hê aan Christus. In die hernude skeppingsorde is die universele betekenis wat agter al ons morele persepsies lê, konkrete en onvervangbare beliggaming gegee deur Jesus.

In die inneem van my plek in hierdie orde, is daar 'n oorgang tussen die objektiewe en subjektiewe modus. En in daardie oorgang, wat gekenmerk word deur die gelowige se vryheid, het die eskatologies-verwagte wêreldverlossing 'n realiteit geword wat alreeds teenwoordig is. 
Wanneer gelowiges die Gees daarom sien as een wat ons krag of vryheid gee wat nie die krag en vryheid van Jesus Christus is nie, raak hul ontspoor. Trouens, Christelike vryheid is nie vryheid om weer die "wet" na te kom nie, maar dit is die deelname in Christus se outoriteit binne die skeppingsorde. Dit is daardie outoriteit waarvolgens ons nie meer slawe is nie, maar kinders.

Christelike vryheid, gegee deur die Heilige Gees, laat gelowiges toe om morele response kreatief te maak. Hierdie outoriteit moet egter nie gesien word as 'n uitdaging van God se outoriteit nie. Dit is die herstel van Adam se heerskap in die natuurlike orde; daardie heerskap waardeur hy aan alles name gegee het.

Die Christen is dus nie een wat nou maak soos hy wil nie, maar 'n mens wat leef $i n$ orde. Hy/sy kan nie kreatief funksioneer met toe oë op die heelal nie.

Kortom beteken Christelike vryheid dus dat die toepaslike patroon van vrye respons tot die objektiewe realiteit, deur die Gees gevorm en tot uitdrukking gebring word.

Paulus beskryf hierdie respons in algemene terme as liefde. Liefde is die omvattende vorm van Christelike etiek; die vorm van menslike deelname in die geskape orde. Dit is self georden en gevorm in ooreenstemming met die orde wat dit in sy voorwerp ontdek. Substantiewe Christelike etiek het die taak om hierdie ordening van liefde na te spoor. Hierdie liefde is dieselfde liefde wat Jesus beoefen het!

\section{Slotsom}

$\mathrm{Na}$ afloop van hierdie studie moet daar tot die slotsom gekom word dat die siening van die wet van Moses as onveranderlike riglyn vir die Christen se lewe, soos blyk uit die Westminster Confession of Faith se hantering daarvan, nie deur die aard van wet as Tora, bevestig word nie. Veeleer het Calvyn in die lig van die bevindinge in hierdie studie 'n beter begrip getoon van die aard van die wet as Tora wanneer hy die riglyn van die Christen se dankbaarheidslewe beskryf.

Die Koninkryk van God in hierdie wêreld sal egter volgens die skrywer wonderlik gedien word indien gelowiges in die $21^{\text {ste }}$ eeu die aard van wet as Tora, as Nuwe Testamentiese kinders van God, opnuut begryp en uitleef. 


\section{Bibliografie}

Allison, DC 1993. The new Moses: A Matthean typology. Minneapolis: Fortress.

Bottéro, J 1992. The 'Code' of Hammurabi, Mesopotamia: Writing, Reasoning, and the Gods. Chicago: University of Chicago Press.

Brown, F, Driver, SR, \& Briggs, CA 1966. Hebrew and English lexicon of the Old Testament. Oxford: Claredon.

Calvyn, J 1984. Institusie van die Christelike godsdiens. Potchefstroom: Calvyn Jubuleum Boekefonds.

Carson, DA 1984. Matthew. The Expositor's Bible Commentary. Grand Rapids: Baker.

Dumbrell, WJ 1981. 'The logic of the role of the law in Matthew V 1-20', Novum Testamentum, XXIII, I, 1-21.

Dumbrell, WJ 1984. Covenant and Creation: A Theology of the Old Testament Covenants. Paternoster, London.

Dunn, JDG 1988. Word Biblical Commentary: Romans 1-8. Nashville: Thomas Nelson.

Evangelical Presbyterian Church, 2010, The Westminster Confession of Faith and Catechisms in Modern English. Livonia, Michigan: Presbyterian and Reformed Publishing Company.

Fishbane, M 1985. Biblical Interpretation in Ancient Israel. Clarendon: Oxford.

Fried, L 2001. You Shall Appoint Judges: Ezra's Mission and the Rescript of Artaxerxes, in (ed.), James W Watts, Persia and Torah: The Theory of Imperial Authorization of the Pentateuch. Atlanta: Society of Biblical Literature. pp. 27-84.

Gese, H 1981. 'The Law”, in Gese, H., (ed.), Essays on Biblical Theology. Minneapolis: Augsburg Publishing house. pp. 60-92.

Hays, RB 1993. Echoes of Scripture in the Letters of Paul. Yale University: Yale University Press. 
Hays, DP 2001, 'Applying the Old Testament law today', Bibliotheca Sacra. $158,21-35$.

Holwerda, DE 1995. Jesus \& Israel. One Covenant or two? Grand Rapids, Michigan: Eerdmans.

Hesselink, IJ 1997. Calvin's first catechism: A commentary. Louisville: John Knox.

Kaiser, WC 1996. The law as God's gracious guidance for the promotion of holiness, in Bahnsen, GL, Kaiser, WC, Moo, DJ, Strickland, WG, VanGemeren, WA (eds.), Five views on Law and Gospel. Grand Rapids, Michigan: Zondervan. pp. 177-200.

Kline, MG 1963. Treaty of the Great King: The Covenant structure of Deuteronomy. Grand Rapids: Eerdmans.

Koehler, L \& Baumgartner, W 1958. Lexicon in Veteris Testamenti libros. Leiden: Brill.

Krause, JS 2015. 'The Grace of God in the Law of Moses: A Second Look at Israel's Written Code', Fidei et Veritatis: The Liberty University Journal of Graduate Research, Volume (online) 1 issue 2, pp. 1-18.

Loader, JA 2001, 'Law and Gospel in the Pentateuch organisation,' Hervormde Teologiese Studies, 57, 70-85.

Mann, $\mathrm{W}$ 1988. The book of the Torah. The narrative integrity of the Pentateuch. Louisville: John Knox.

Milgrom, J 2004, Leviticus: A Book of Ritual and Ethics. Minneapolis: Continental Commentary, Fortress Press.

Moo, D 2000. Romans: NIV Application Commentary. Grand Rapids: Zondervan.

Moltmann, J 1967. Theology of hope. New York: Harper \& Row.

O’Donavan, O 1994. Resurrection and Moral Order, An outline for evangelical ethics. Grand Rapids: Eerdmans. 
Otto, E 1996. The Preexilic Deuteronomy as a Revision of the Covenant Code, in idem, Kontinuum und Proprium: Studienzur Sozial- und Rechtsgeschichte des Alten Orients und des Alten Testaments, Orientalia Biblica et Christiana 8. Wiesbaden: Harrassowitz.

Poythress, V 1991. The shadow of Christ in the law of Moses, Philipsburg, New Jersey: Presbyterian \& Reformed.

Patrick, D 1985. Old Testament Law. Atlanta: John Knox

Preuss, HD 1995. Old Testament Theology. Louisville, Kentucky: John Knox.

Ryken, L, Wilhoit, J, Longman, T, Durec, C, Penney, D, \& Reid, DG 2000. 'Dictionary of Biblical imagery: The temple', in Sholar's Library: Gold. CD-ROM, Logos Bible Software.

Sailhamer, JH 1991. 'The Mosaic law and the theology of the Pentateuch', Westminster Theological Journal, 53, 241-261.

Schmitt, H 1982. 'Redaktion des Pentateuch im Geiste der Prophetie', Vetus Testamentum, 32, 170-189.

Van Bruggen, J 1999. Matteus: Het evangelie voor Israël. Kampen: Kok.

Watts, J 1999. 'Reading Law: The Rhetorical Shaping of the Pentateuch', Biblical Seminar, 59,136-137/Sheffield: Sheffield Academic Press.

Wells, B 2008. 'What Is Biblical Law? A Look at Pentateuchal Rules and Near Eastern Practice', The Catholic Biblical Quarterley, 70, 223-243.

Wells, B, Gane, R, Cole, D \& Carpenter, E 2009. Exodus: Zondervan Illustrated Bible Backgrounds Commentary, Kindle. MI: Zondervan Grand Rapids.

Wenham, G 2003. Exploring the Old Testament, volume 1: The Pentateuch. London: SPCK.

Westbrook, R 1989. 'Cuneiform Law Codes and the Origins of Legislation,' ZA, 79, 201-22.

Wright, JH 1983. An Eye for an Eye: The place of Old Testament Ethics Today. VP Dowers Grove Illinois: IVP 
Wright, NT 2004. The climax of the covenant. Minneapolis: Fortress.

Wright, NT 2016. The Day the Revolution Began: Reconsidering the Meaning of Jesus's Crucifixion, New York: HarperOne. 